\title{
A.C.R.L. in Action
}

By N. Orwin Rush

$\mathrm{T}$ HIs is not a report. It is a story in fragments, and you are the chief characters in it. Its location for the moment is in Chicago, but it doesn't stay there, it moves from Maine to Florida to California and to points in between. A.C.R.L. membership is increasing rapidly-A.C.R.L. members are working industriously. The complete story of the activities of A.C.R.L. could not be related in this limited space, but here are some of the parts.

The four special committees set up at San Francisco in July 1947 have now been in action a little more than a year.

Special Membeŕship-Mr. Wayne S. Yenawine was chairman of this committee until September I, 1948, at which time Mr. Robert Severance took over. There is at least one member from each state, Canada, Alaska, and Hawaii. One of the first activities of the committee was to send out 2220 letters to college, university, and reference librarians who were members of A.L.A., but who had not designated A.C.R.L. as their choice of division, inviting them to affiliate with the division. An A.C.R.L. membership page was prepared for the November 1947 issue of the A.L.A. Bulletin. A list of new 1948 members has appeared in College and Research Libraries. The membership of the division at the end of the year was around 3700 which is an increase of nearly 1000 members in 1948. The present personnel of the committee is: Stanley Hoole, John S. Mehler, Patricia Paylore, Marvin A. Miller, Allan R. Laursen, Everett T. Moore, Eleanor B. Mercer, Henry J. Waltmeade, Dorothy Bridgewater, Ruth Alford, Frank J. Bertalan, Louise Richardson, Margaret $M$. Jemison, Carl Stroven, Eldon C. Hart, William L. Hyde, Howard Winger, John H. Moriarty, Norman L. Kilpatrick, Downing P. O'Harra, Edna J. Grauman, Robert H. Trent, Edward C. Heintz, Howard Rovelstad, Ruth K. Porritt, Jackson E. Towne, David R. Watkins, Mahala Saville, Felix E. Snider, Merwin M. Moores, Richard A. Farley, James J. Hill, Thelma Brackett, Genevieve Porterfield, Ira A. Tumbleson,
G. F. Shepherd, Joseph Brewer, W. P. Kellam, Della Mathys, Howard F. McGaw, Edmon Low, Margaret Markley, Ralph McComb, Marion Kesselring, J. Mitchell Reames, Lois Bailey, J. H. Lancaster, Edith Rich, Louise E. Robinson, Louise Savage, Helen Johns, Helen Northup, Esther Clausen, and Robert W. Severance, chairman.

Special Committee on Recruiting. The committee has made an excellent beginning this year toward a long range plan for attracting high caliber recruits. It has worked closely with the Joint Committee on Library Work as a Career contributing substantially to the preparation of the joint committee's recruiting folder 10,000 Careers with a Challenge. A.C.R.L.'s committee has issued its own Recruiting Bulletin-to date these bulletins have been four in number, and they were issued to all A.C.R.L. institutional members. The committee has constantly urged the discussion of recruiting problems at local, state, and regional meetings, and two of its members presented papers on the subject at one of the general A.C.R.L. meetings at Atlantic City. The committee personnel is: Dale M. Bentz, Beverley Caverhill, Rev. James J. Kortendick, Mrs. Frances Lander Spain, Katharine M. Stokes, Eugene P. Watson, Gonzalo Velazquez, Harry C. Baùer, and Lawrence S. Thompson, chairman.

Special Committee on the Educational Preparation and Qualifications Needed by College, University, and Reference Librarians. The committee has held a number of meetings and considerable correspondence mainly to determine its course, and has come up with a proposal to hold a series of small conferences. For the present it will be concerned only with minimum requirements. The recommendations emerging from these conferences are to be submitted to a larger representative group of consultants for criticism and revision. The personnel of the committee is: Mary Clay, Robert Muller, Jack Dalton, Edward Chapman, Katherine Anderson, Robert W. Christ, Florence B. Murray, W. S. Hoole, William Kozumplik, and Jerrold Orne, chairman. 
Special Committee to Consider the FiNancial Needs of A.C.R.L. and to Suggest a Program for Their Realization. Mr. Lundy has gone over the financial situation very carefully at Headquarters and at present is hoping to work closely with the Fourth Activities Committee. The personnel of the committee is: Clyde H. Cantrell, G. Flint Purdy, Stephen McCarthy, Lola Rivers Thompson, Herman Henkle, Arthur M. McAnally, and Frank A. Lundy, chairman.

\section{Standing Committees}

Committee on Publications. During the past year Dr. Richard H. Logsdon has been chairman of this committee to integrate the publishing interests of the various sections. The committee has established at Headquarters the beginning of what may become a very important collection of documents reflecting current procedures in the administration of college, university, and reference libraries. The committee prepared a statement, describing the project and requesting the material, which went to all of the college and university libraries in this country and Canada. The committee this year is bringing particular attention to bear upon its responsibility of making a survey of publication needs and of taking a more active role in encouraging needed publications and not limiting its work to the reviewing of manuscripts brought to its attention. Under the leadership of $\mathrm{Mr}$. Lewis Branscomb, as chairman this year, we can expect the committee to continue to make definite headway in this undertaking. There is great hope and encouragement that a larger and better line of needed publications, research, and investigation will emerge. This is a task of large proportions, and the committee needs the full support of all in carrying out its work in this field. The personnel of the committee is: Mary N. Barton, Richard H. Logsdon, B. Lamar Johnson, Maurice F. Tauber, Margaret M. Field, Guy R. Lyle, Katharine M. Stokes, Lawrence S. Thompson, and Lewis Branscomb, chairman.

Committee on College and University Library Buildings. Dr. Robert A. Miller, Director of Libraries, Indiana University, is chairman of this committee to assist those who seek advice relative to new buildings, alterations, library furniture, and equipment.
It is the policy of the committee at present to urge librarians faced with a building program to call in a library consultant who will be capable of making a careful and thorough survey of the needs and problems of the college or university. The committee considers the survey as one of the critical points in proper library planning with the principal job of the consultant being to help in the formation of a well-thought-out and clearly stated program. The committee is prepared to recommend consultants and is concentrating its energies on the "education" of consultants. At the encouragement of the committee Headquarters is collecting pictures and plans. Through the help of the A.C.R.L. Executive Secretary's office the committee has available a list of libraries planning new buildings as well as a list of those who have recently completed buildings, and just recently it undertook a survey to find out how well librarians were satisfied with their new buildings. The replies received brought a number of "musts" as well as unsatisfactory features of most of the buildings. Thus was gained a knowledge of building features that had stood the test of use. The committee sponsored a clinic on college library buildings at the Atlantic City Conference at which time a number of librarians presented their plans for discussion and criticism. The personnel of the committee is: Harlan C. Brown, Margaret Briggs, Mrs. Eulin K. Hobbie, Donald A. Woods, and Robert A. Miller, chairman.

Committee on Budget, Compensation, and Schemes of Service. This is also a sub-committee of the A.L.A. Board on Personnel Administration. The long-awaited score card, a supplement to the Classification and Pay Plans for Libraries in Institutions of Higher Education, by which a library may measure its own effectiveness has been prepared by the committee under the chairmanship of David Clift and will probably be published by A.L.A. in February. Early in 1948 a second edition of the Classification and Pay Plans ... was issued. The committee is now at work on a similar volume for professional schools. The personnel of the committee is: Ruth T. Power, Eleanor Witmer, Raymond P. Morris, Robert Vosper, E. G. Freehafer, Eileen Thornton, Evelyn Fritz, W. R. Roalfe, and Ralph Parker, chairman. 
Committee on Finances of College and Research Libraries. Printing costs have soared beyond reason during the past few years making the publishing of our official journal College and Research Libraries increasingly difficult to finance. One of the ten cardinal policies proposed by A.C.R.L.'s Committee on Policy was to support College and Research Libraries. The journal has recently been increased to 96 pages, and it is the desire of the Publications Committee and the Board of Directors to continue to expand the journal if adequate support is forthcoming. The first steps to help meet the rising costs were to increase the subscription price by $\$ \mathrm{I} .00$ and to make space available for advertising purposes. Advertising for the first year was handled by A.L.A. However, this agreement was not financially successful for A.L.A., and a new arrangement has been effected whereby the advertising will now be handled by this committee.

The next step was to put on an extensive campaign to increase the number of subscriptions. The committee is working diligently on this phase of its work with good results. The personnel of the committee is: David K. Berninghausen, Mary Herrick, Francis W. Allen, Mary V. Gaver, and Mrs. Ada J. English, chairman.

Committee to Study Library Standards of Professional Schools. The committee is attempting to work out the cardinal points from which the evaluation of a library might be determined. The committee hopes to point out valid criteria to measure the effectiveness of library service, criteria that would be independent of organization. Such a committee report might be used as an instructional guide to the accrediting associations for their use in accrediting libraries. The personnel of the committee is: Eugene $\mathrm{H}$. Wilson, Ruth T. Power, and Ralph Parker, chairman.

\section{Other Activities}

It has been suggested that A.C.R.L. might attempt to encourage closer relations with foreign educational institutions. One step toward this is the recent decision of the Board to give one hundred subscriptions of College and Research Libraries to foreign libraries for the year 1949. It was felt that this would be of particular value to those libraries who are unable to subscribe because of currency restrictions. The one hundred libraries have been selected and are now receiving the journal.

Plans are being made for a special number of College and Research Libraries in honor of the tenth year of its appearance.

An up-to-date outline manual for the use of section officers has been prepared. Among other things this manual tells about the mimeograph service and addressograph mailing which Headquarters and the A.C.R.L. Executive Secretary's office are now prepared to make available for sections and committees.

Progress is being made on a special study regarding faculty status to be made in collaboration with the University of Chicago. From the result of a questionnaire sent out from the office of the A.C.R.L. Executive Secretary last spring and other data on this subject, a considerable amount of useful information is already available.

\section{Sections}

The work of the seven different sections always brings in a series of interesting actions. For the most part they are strong and significant working groups holding excellent and worthwhile meetings at the annual and midwinter conferences. A number of them issue a newsletter from time to time. The Junior College Libraries Section is particularly concerned over the lack of adequate up-to-date book selection tools for junior colleges. Definite progress is being made with the $\mathrm{H}$. W. Wilson Co. for working out plans for a Standard Catalog for Junior Colleges. In the meantime Miss Mary Clay, Librarian of Northeast Junior College at Monroe, La., has prepared a list of aids which she has found useful in book selection - mimeographed copies of this list are available at the Executive Secretary's office. To facilitate the work of the section regional representatives have been set up who have their respective responsibilities for the work of the section. One of the most significant moves, and one in keeping with a very important suggested activity of A.C.R.L. (that of establishing and maintaining cordial relations with, and presenting the library point of view to, national and regional educational associations) was the establishment of a com- 
mittee of the American Association of Junior Colleges to identify and study junior college library problems. This committee has come up with a list of problems in need of investigation.

Two of the sections, the Junior College and the Engineering School Sections, are now working on a directory of their members. The directory being prepared by the engineers will include the listing of the staff of engineering libraries starring those who are members of A.C.R.L.

Another project underway by the Engineering School Libraries Section is a survey of salaries, schedules, collections, staffs, budgets, etc., prevailing in engineering school libraries.

The Agricultural Libraries Section, in keeping with A.C.R.L.'s special emphasis upon strengthening our association, has recently undertaken a special membership drive. It has also been particularly concerned about bringing proper library standards to the attention of the various general and professional accrediting agencies in an effort to better the position of libraries in the landgrant colleges.

The members of the Reference Librarians Section have considered seriously the purpose and activities of their section. The very important Committee on New Reference Tools has been re-activated.

The University Libraries Section during the past year placed their emphasis upon the functions of rare books, centering their annual meeting around this subject. They are planning to publish in College and Research Libraries the three papers which were given at their annual meeting- "The Need for Rare Books in the University Library," by John Cook Wyllie, of the University of Vir- ginia Library; "The Administration and Policy Relating to Rare Books in the University Library," by Lawrence Clark Powell, of the University of California Library at Los Angeles; and "The Organization and Service of Rare Books in the University Library," by John Alden, of the University of Pennsylvania Library.

The College Libraries Section has been particularly concerned with audio-visual materials and faculty status for professional librarians.

The members of the Libraries of Teacher Training Institutions Section have placed special emphasis upon the integration of library materials with teaching. The proposals of their committee on Four Year Goals should bring a new vigor into the work of the section.

You who read this story are the ones who have made it and are the ones to make it continue. I trust that enough has been told to show that A.C.R.L. can assist college, university, and reference librarians in the solution of their problems. As the Brown report stresses, the majority of A.C.R.L. members believed very definitely that much of the work of the Association should be done through committees with a central office to stimulate and coordinate their activities. It is, then, through the activities of sections and committees such as briefly described here that the Executive Secretary hopes to make a contribution to the growth of A.C.R.L. If we can make A.C.R.L. an organization in which we all participate and upon which we can all call for help, then the Association will have moved to a new high level. We all have a direct and important part in the problems and affairs of the Association, and the interest of each is the interest of A.C.R.L.

\section{Brief of Minutes}

\section{(Continued from page 7o)}

this was the original thinking when the committee was formed.

The question of a circulation section which had been proposed was brought up. The board felt that because of the present state of flux of the A.L.A. the project should be discouraged at this time. They also felt that A.C.R.L. should be steered away from further fragmentation.

The meeting adjourned.

N. Orwin Rush, Executive Secretary 